\title{
Predicting Corporate Failures Using Multi Discriminant Analysis and Current Ratio: An Empirical Application to Philippines Stock Exchange
}

\author{
Cerenio Adriatico \\ Southern Leyte State University - College of Business and Management, San Juan, Southern Leyte, Philippines
}

\begin{abstract}
Corporate failure models can be broadly classified into two groups: quantitative models, which are mainly based on published financial information and qualitative models, which are based on an internal assessment of the company concerned. Both types attempt to determine characteristics, whether financial or non-financial, which can then be used to distinguish between surviving and failing companies. This study sought to predict companies that are potential to corporate financial distress utilizing the Altman ZScore model and current ratio. Forty-five companies currently listed on the Philippine Stock Exchange were randomly selected, and their corresponding audited financial statements published online were downloaded and assessed using the financial ratios. Findings of the study revealed, 35 companies have been chosen potential for becoming financially distressed when subjected to the Altman Zscore model. On the other hand, 12 companies were also found experiencing financial difficulties based on current ratio analysis. Accordingly, these companies have classified either failure or non-failure based on Altman and current ratio. The study concluded both the Altman Z-Score Model and current ratio are financial analytical tools investors and financial analysts can use in assessing the financial health of the company before investing or buying the stock. For businesses having low or declining Z-index, requires an indepth analysis of the accounts in the financial statements to verify the cause of the problem or potential risk.
\end{abstract}

Keywords: financial distress, Altman Z-Score Model, Current Ratio, failure companies, non-failure companies

\section{Introduction}

The use of financial statements and reports in predicting corporate failure has been a topic of much interest in accounting and finance researchers since the mid 1960's (Poston, et.al. 2011) with the goal of assessing the usefulness of selected accounting variables in identifying between failed and non-failed firms with failures most often defined as the inability of firms to pay its obligations as they mature (Beaver, 1966). The study of Beaver was considered one of the classic works in the area of financial ratios analysis and established the standards for other researchers on bankruptcy predictors (Altman, 2000). Operationally, firms have failed when any of the following conditions have occurred: bankruptcy, going-concern, financially distress, bonds default, non-payment of preference shares dividends, insolvency or overdrawn bank accounts (Poston, et.al. 2011, Shumway, 2001, Hambrick, et.al., 1988, Beaver, 1966 and Altman, 1968).

Predicting bankruptcy is one of the leading decision criteria problems since it affects the entire lifespan of the business (Mohammed et al., 2012). Subsequently, failure results in excessive costs to firms, organizations, the society, and the economy in general (Ahn and Kim, 2000). The emergence of assessing corporate failures especially that of domestic companies and trans-national corporations attracted a significant number of academics and professionals of developing optimal financial accounting prediction models in meeting their specific interest and growing needs of businesses (Mohammed et al. 2012). Studies conducted by Altman (2000) as cited by Mohammed et al. (2012) using financial ratios to forecast the occurrence of business failure predicted $94 \%$ accuracy one year before bankruptcy occurred and $72 \%$ two years before the actual incident.

In predicting failure Altman (1968) developed the Z-Score Model applying multi-discriminant analysis (MDA) which is based on the sample of the dataset of publicly held U.S manufacturing companies in 1968 but has since been reestimated to make the model applicable to all types of businesses. Subsequently, this model became widely utilized in actual practice. Altman used five financial ratios considered significant in predicting business failure consisting of working capital over assets, retained earnings over total assets, earnings before interest and taxes over the total assets, a market value of equity over the total value of liabilities, and sales over total assets. These ratios represented the independent variables and assigned a relative weight of each variable. Altman constructed the model using the following equation:

$\mathrm{Z}=0.012 \mathrm{X}_{1}+0.014 \mathrm{X}_{2}+0.033 \mathrm{X}_{3}+0.006 \mathrm{X}_{4}+0.999 \mathrm{X}_{5}$ where-

$\mathrm{X}_{1}=$ Working Capital/Total Assets

$\mathrm{X}_{2}=$ Retained Earnings/Total Assets

$\mathrm{X}_{3}=$ Earnings Before Interest and Taxes/Total Assets

$\mathrm{X}_{4}=$ Market Value Equity/Book Value of Total Liabilities

$\mathrm{X}_{5}=$ Sales/Total Assets

$\mathrm{Z}=$ Overall index

Each ratio captures a different dimension of profitability or risk as follows (Wahlen, et al. 2011, Weygandt, et al., 2012, Brigham and Houston, 2014, Ross, et al., 2010):

1) Networking capital/Total assets: The proportion of total assets comprising relatively liquid of net current assets 


\section{International Journal of Science and Research (IJSR) \\ ISSN: 2319-7064}

ResearchGate Impact Factor (2018): 0.28 | SJIF (2018): 7.426

(current assets-current liabilities). This ratio measures the firm's short-term liquidity risk.

2) Retained earnings/Total assets: This represents the accumulated profitability and relative age of firms.

3) Earnings before interest and taxes (EBIT)/Total assets: This ratio represents a variant of return on assets (ROA) and also measures current profitability.

4) The market value of equity/Book value of total debt: This represents a form of the debt-to-equity ratio but incorporates the market's assessment of the value of the firm's shareholders' equity. It measures long-term solvency risk and the overall market assessment of the profitability and uncertainty of the firm.

5) Sales/total assets: This is similar to total assets turnover and indicates the ability of a firm to use assets to generate revenues.

In applying this model, Altman found that Z-scores of less than 1.81 indicated a probability of bankruptcy, while Zscores of higher than 3.0 signified a low chance of bankruptcy. Scores between 1.81 and 3.0 denote a gray area.

Meanwhile, the current ratio (current assets/current liabilities) is used to evaluate the liquidity and capital of the current critical period(Greminger et al., 1996, Agarwal, et al., 2008, Nam, et al., 2008, Belovary, et al., 2007). The current ratio is a financial indicator that measures whether or not a firm has the available resources to pay its debt in one year or less (Wahlen et al. 2011, Warren, et al., 2009, Ross, et al. 2010, Mohammed, et al. 2012). The current ratio is the prime essential liquidity test. A current ratio of greater than or equal tone one, indicates the current assets are meeting short-term obligations while a ratio of lesser than one signifies liquidity issues (Tirapat, 1999, Cowen and Hoffer, 1982, Mohammed, et al., 2012). For instance, businesses in cyclical industries may maintain a higher current ratio to remain solvent (Ali, 2008, Jones, 1987) but shareholders, on the other hand, prefer a lower current ratio so that more assets are utilized for the growth of the business (Ali, 2008, Mohammed, et al., 2012).

Overall, these financial ratios provide meaningful indicators of the performance and health condition of firms. These set of coefficients have been used for many years by investors, creditors, shareholders, auditors, suppliers, lenders, employees, and stakeholders who may have incurred substantial losses resulting from business failure (Mohammed et al. 2012, Chava and Jarrow, 2004, Platt, et al. 2002). These financial ratios are divided into five components comprising of profitability ratios, liquidity ratios, activity ratios, financial leverage ratios, and capital market ratios.

It has been widely claimed the use of Altman, and current ratio models were found useful in predicting corporate bankruptcy when applied to several corporations in the past(Nam et al., 2008, Bellovary, et al., 2007, Zeytinoglu, E., \&Akarim, Y. D., 2013). The uses of these models, however, have not been studied at length for Philippine companies due to the shortage of analytical studies and scientific researchers. Thus, this paper investigated the validity of the two widely financial tools in assessing the potential risks of companies involved in this study. In this paper, thresholds for the financial failure of selected companies were utilized to distinguish between failure and non-failure companies when assessed using the Altman- $Z$ Score and current ratio respectively.

\section{Theoretical and Conceptual Framework}

This study is anchored on the theory of ratio analysis by Beaver (1966). Applying the cash flow framework, Beaver posited the assumptions the more substantial the reservoir and the net liquid asset flow, the smaller the probability of failure. On the contrary, the enormous amount of debt held and more massive expenditures for operations, the higher the likelihood of failure. It investigated the predictive ability of financial ratios and able to distinguish between failure and non-failure firms. Also used in the study is the Altman Z Score Model a linear equation developed by Edward Altman (1968) for predicting bankruptcy utilizing a multidiscriminant analysis. Firms can be distinguished either potential or non-potential for bankruptcy when assessed using the financial ratios.

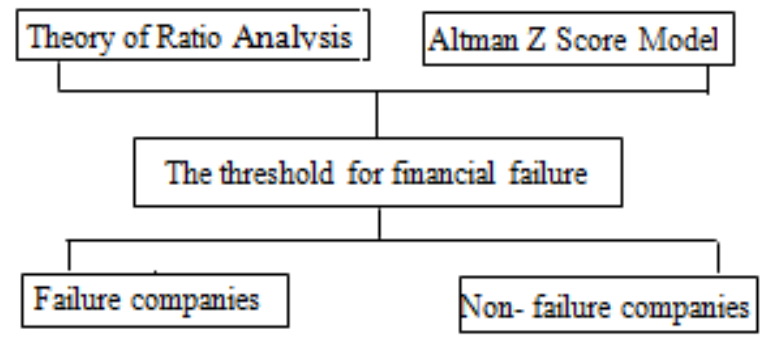

Figure 1: The theoretical and conceptual framework of the study

\section{Methods}

This study used a descriptive analysis design. An analysis is a careful examination to determine new information as well as significant relationship and at the same time expand or substantiate existing knowledge. The investigation conducted was based on the financial statements of 45 companies downloaded from the Philippine Stock Exchange Electronic Disclosure Generation Technology or PSE EDGE. EDGE is a state-of-the-art, fully automated system that facilitates the efficient processing, validation, submission, distribution, and analysis of time-sensitive disclosure reports submitted to the Philippine Stock Exchange. In calculating the current ratio and Altman ZScores, the study used the following accounts: Current Assets, Current Liabilities, Total Assets, Retained Earnings, Stockholders' Equity, Gross Revenue and Income from operations, and Total Liabilities. These financial reports are fully disclosed in PSE EDGE and dated 31 December 2015.

\section{Results and Discussion}

Table 1: Profiles of industries and number of companies studied

\begin{tabular}{|c|c|}
\hline Industries & Number of companies \\
\hline Food, beverage, tobacco & 12 \\
\hline Holding firms & 7 \\
\hline Electricity, energy, power, and water & 5 \\
\hline
\end{tabular}

\section{Volume 8 Issue 4, April 2019 www.ijsr.net}




\section{International Journal of Science and Research (IJSR) \\ ISSN: 2319-7064}

ResearchGate Impact Factor (2018): 0.28 | SJIF (2018): 7.426

\begin{tabular}{|c|c|}
\hline Media & 4 \\
\hline Hotel, resorts, and leisure & 3 \\
\hline Transportation services & 3 \\
\hline Banks & 2 \\
\hline Mining and oil & 2 \\
\hline Telecommunications & 2 \\
\hline Education & 2 \\
\hline Casinos and gambling & 1 \\
\hline Small, medium, and emerging board & 1 \\
\hline Property & 1 \\
\hline Total & 45 \\
\hline
\end{tabular}

The food, beverage, and tobacco sector represent $27 \%$ of the total number of companies studied. Holding firms represent $15 \%$ of the sample. Meanwhile, the electricity, energy, power, and water and media sectors account for $11 \%$ and $9 \%$ respectively.

Table 2: Threshold of Altman Z Score and Current Liquidity Ratio

\begin{tabular}{|c|c|c|}
\hline Financial situation & Altman Z score value & Current ratio value \\
\hline Failure company & $<1.81$ & $<1.1$ \\
\hline Non-failure company & $>2.99$ & $=>1.1$ \\
\hline
\end{tabular}

In applying this model, Altman found that Z-scores of less than 1.81 indicated a probability of bankruptcy, while Zscores of higher than 3.0 signified a low possibility of bankruptcy. Scores between 1.81 and 3.0 denote a gray area. Similarly, a current ratio of less than 1.0 means helplessness of the firm to pay its short-term creditors on time.

Table 3: Results of current ratio and Altman Z-Score tests of companies studied

\begin{tabular}{|c|c|c|c|}
\hline Company & Company & $\begin{array}{c}\text { Current } \\
\text { Ratio }\end{array}$ & \begin{tabular}{|c} 
Altman \\
Z-Score \\
\end{tabular} \\
\hline 1 & Media & 1.9 & 1.55 \\
\hline 2 & Media & 1.8 & 2.20 \\
\hline 3 & Transportation Services & 1.2 & 1.71 \\
\hline 4 & Food, Beverage, Tobacco & 1.3 & 3.09 \\
\hline 5 & Media & 1.2 & 3.26 \\
\hline 6 & Media & 1.3 & 5.08 \\
\hline 7 & $\begin{array}{c}\text { Electricity, Energy, Power, and } \\
\text { Water }\end{array}$ & 1.3 & 1.92 \\
\hline 8 & $\begin{array}{l}\text { Electricity, Energy, Power and } \\
\text { Water }\end{array}$ & 3.4 & 1.60 \\
\hline 9 & Education & 2.5 & 3.04 \\
\hline 10 & Transportation Services & 5.6 & 1.46 \\
\hline 11 & Holding firm & 1.5 & 1.35 \\
\hline 12 & Food, Beverage, Tobacco & 1.6 & 3.04 \\
\hline 13 & Food, Beverage, Tobacco & 2.3 & 2.68 \\
\hline 14 & Holding firm & 2.8 & 3.06 \\
\hline 15 & Banks & 0.6 & 0.44 \\
\hline 16 & Holding firm & 1.5 & 1.06 \\
\hline 17 & $\begin{array}{l}\text { Electricity, Energy, Power and } \\
\text { Water }\end{array}$ & 1.1 & 1.88 \\
\hline 18 & Banks & 0.8 & 0.11 \\
\hline 19 & Food, Beverage, Tobacco & 4.3 & 2.93 \\
\hline 20 & Property & 3.1 & 2.26 \\
\hline 21 & Food, Beverage, Tobacco & 1.0 & -1.98 \\
\hline 22 & Telecommunications & 0.8 & 1.19 \\
\hline 23 & Food, Beverage, Tobacco & 0.7 & 0.98 \\
\hline 24 & Education & 1.1 & 2.29 \\
\hline 25 & $\begin{array}{c}\text { Electricity, Energy, Power and } \\
\text { Water }\end{array}$ & 1.2 & 1.29 \\
\hline
\end{tabular}

\begin{tabular}{|c|c|c|c|}
\hline 26 & Holding firm & 2.1 & 1.25 \\
\hline 27 & Holding firm & 1.1 & 1.18 \\
\hline 28 & Telecommunications & 0.5 & 0.87 \\
\hline 29 & Food, Beverage, Tobacco & 1.5 & 3.35 \\
\hline 30 & $\begin{array}{c}\text { Electricity, Energy, Power and } \\
\text { Water }\end{array}$ & 1.4 & 1.09 \\
\hline 31 & Mining and Oil & 0.3 & -0.15 \\
\hline 32 & $\begin{array}{c}\text { Small Medium and Emerging } \\
\text { Board }\end{array}$ & 3.5 & 3.32 \\
\hline 33 & Mining and Oil & 0.8 & 1.36 \\
\hline 34 & Casinos and Gambling & 2.4 & 1.36 \\
\hline 35 & Food, Beverage, Tobacco & 2.1 & 4.08 \\
\hline 36 & Hotel and Leisure & 0.6 & 1.00 \\
\hline 37 & Holding firm & 3.0 & 0.58 \\
\hline 38 & Hotel and Leisure & 1.7 & 2.01 \\
\hline 39 & Food, Beverage, Tobacco & 0.5 & 0.71 \\
\hline 40 & Food, Beverage, Tobacco & 0.8 & 2.16 \\
\hline 41 & Food, Beverage, Tobacco & 0.6 & -44.21 \\
\hline 42 & Hotel and Leisure & 1.2 & 0.59 \\
\hline 43 & Food, Beverage, Tobacco & 1.4 & 1.15 \\
\hline 44 & Transportation Services & 0.9 & 1.73 \\
\hline 45 & Holding firm & 1.2 & 1.21 \\
\hline
\end{tabular}

Results of the current ratio analysis revealed 12 companies experienced ratios below 1.0 times. It means that for every 1 peso of current liabilities the 12 companies have less than a peso to cover their short-term obligations. Meanwhile, the current ratio of 33 companies appeared to be in better shape as their ratios were higher than one peso. It relatively shows these companies have sufficient current assets relative to their current liabilities, a good sign of sound financial health status. In practice, the current ratio is one of the liquidity measures popularly utilized and considered a more dependable indicator of being liquid than working capital (Weygandt et al., 2012). For instance, two or three companies having a similar amount of working capital may significantly differ in their actual current ratios. (Ross, et al. 2010, Brigham and Houston, 2014) suggested several shortterm creditors preferred to provide credit to companies with higher current ratios.

According to the Altman Z Score, 35 companies have scores between -44.21 and 2.99. Companies were obtaining these scores either experiencing deteriorating financial future or high probability of bankruptcy shortly. Under Altman, is deemed to be a classified failure if its $\mathrm{Z}$ index is below 3.0. Additionally, companies with negative scores indicated below mean score. The $\mathrm{Z}$ index is more than an assessment of bankruptcy and insolvency. Decomposing the component ratios, it reveals critical issues and risks faced by companies assessed by traditional ratio analysis: liquidity concerns are measured in $\mathrm{X}_{1}$; shareholders claims against resources are measured in $\mathrm{X}_{2}$; profitability is measured in $\mathrm{X}_{3}$; long term solvency risk is measured in $\mathrm{X}_{4}$; asset utilization is measured in $\mathrm{X}_{5}$. The following table summarizes the results of the test.

Table 4: Financial Status of Companies Studied

\begin{tabular}{|c|c|c|}
\hline \multirow{2}{*}{ Measurements } & \multicolumn{2}{|c|}{ Number of Companies } \\
\cline { 2 - 3 } & Failure & Non-Failure \\
\hline Altman Z- Score & 35 & 10 \\
\hline Current ratio & 12 & 33 \\
\hline
\end{tabular}

\section{Volume 8 Issue 4, April 2019} www.ijsr.net 


\section{International Journal of Science and Research (IJSR) \\ ISSN: 2319-7064}

ResearchGate Impact Factor (2018): 0.28 | SJIF (2018): 7.426

The analysis in this paper was restricted to the sample companies selected from the Philippine Stock Exchange using the Altman Z-Score Model and current ratio. Thresholds were used in identifying between failure and nonfailure company listed in Table Number 3. Under Altman, a company is deemed to be the classified failure if its $\mathrm{Z}$ index is below 3.0. For the current ratio, a company is categorized as the failure if the ratio is below 1. For a simple analysis, a current ratio of .80 reads as $.80: 1$ meaning for every P1.00 debt, the company is capable of paying off up to P0.80 centavos. Thus, this particular company needs to look for additional sources to cover the balance. In real practice, some of the companies identified as failure usually run some advertisements in Philippine television during prime time; however, nobody noticed the predicament since a majority of the failure companies reported income from operations. By merely reading the financial information published in PSE EDGE it appeared these companies are in good financial condition, but the careful analysis should be carried out using the model to assess the potential danger the company is facing. The findings of this study provided credence to the degree of financial analysis results (Mohammed and Soon, 2012, Brigham and Houston, 2014). Over the years, some researchers suggested the use of financial ratios and Altman model in assessing potential risk for bankruptcy were deemed useful (Altman, 2002, Chava and Jarrow, 2004, Nissim and Penman, 2001, Wahlen, et al., 2011).

Whenever financial ratios are utilized to analyze a company, it is important to note that no economic analysis technique is perfect (Gerantonis et al., 2009, Summers and Sweeney, 1998, Karamzadeh, 2013). For instance, the Z-Score is merely reliant on the underlying financial data reported by the company. If the company is window-dressing the presentation of the financial statements in cohorts with the external auditors, then the financial statements will not reflect a fair representation of the financial statements published. The Enron scandal (Petrick, and Scherer, 2003) in 2001 was a celebrated case in fraudulent reporting of the financial statements (Li, 2010, Grey, 2003, Nelson, et al., 2008). The collapse, unfortunately, led to the demise of the world's most prominent accounting firm, Arthur Andersen.

\section{Conclusion}

At a minimum, the Z- Score model and current ratio are among the analytical tools investors can use in monitoring the safety of their investments. Potential investors, on the other hand, will be benefited if they are going to assess the historical financial data of the particular company using the tool before making their investments. A low or declining $\mathrm{Z}-$ Score index, definitely requires in-depth analysis to determine the cause of the potential risk. Note that financial accounting information is significantly affected by policies, estimates, and assumptions. Accounting standards permit different accounting policies which prevent comparability; thus there is the tendency the use of ratio analysis is somehow less useful in such conditions. One potential issue is an application of depreciation. Different depreciation methods used by companies affect the financial statements differently and difficult to compare. There are times that companies may engage in window dressing of the financial statements enticing prospective investors to invest in a particular business. In general, false financial accounting data provide an incorrect ratio. Hence, investors should be conscious enough before buying those shares traded on the market.

\section{References}

[1] Poston, K. M., Harmon, K., \&Gramlich, J. D. (2011). A test of financial ratios as predictors of turnaround versus failure among financially distressed firms. Journal of Applied Business Research (JABR), 10(1), 41-56.

[2] Beaver, W. H. (1966). Financial ratios as predictors of failure. Journal of accounting research, 71-111

[3] Shumway, T. (2001). Forecasting bankruptcy more accurately: A simple hazard model*. The Journal of Business, 74(1), 101-124.

[4] Hambrick, D. C., \&D'Aveni, R. A. (1988). Large corporate failures as downward spirals. Administrative Science Quarterly, 1-23.

[5] Altman, E. I. (1968). Financial ratios, discriminant analysis and the prediction of corporate bankruptcy. The journal of finance, 23(4), 589-609.

[6] Mohammed, A. A. E., \& Kim-Soon, N. (2012). Using Altman's model and current ratio to assess the financial status of companies quoted in the Malaysian stock exchange. International Journal of Scientific and Research Publications, 2(7), 1-11.

[7] Ahn, B. S., Cho, S. S., \& Kim, C. Y. (2000). The integrated methodology of rough set theory and artificial neural network for business failure prediction. Expert systems with applications, 18(2), 65-74.

[8] Altman, E. I. (2000). Predicting financial distress of companies: Revisiting the Z-score and ZETA models. Stern School of Business, New York University, 9-12.

[9] Wahlen, J., Baginski, S., Bradshaw, M. 2011 Chapter 5. Risk Analysis Financial Reporting, Financial Statement Analysis, and Valuation: A Strategic Perspective 7th Edition CENGAGE Learning/South-Western

[10] Weygandt, J., Kieso, D., Kimmel, P. 2012 Chapter 19. Financial Statement Analysis. Accounting Principles, 10th Edition Wiley and Sons, Inc.

[11] Brigham, E. and Houston, J. 2014. Chapter 3. Analysis of Financial Statements. Fundamentals of Financial Management 13th Edition CENGAGE Learning

[12] Ross, S., Westerfield, R., Jordan, B. 2010 Chapter 3. Working with Financial Statements Fundamentals of Corporate Finance McGraw - Hill/Irwin

[13] Greninger, S. A., Hampton, V. L., Kitt, K. A., \&Achacoso, J. A. (1996). Ratios and benchmarks for measuring the financial well-being of families and individuals. Financial Services Review, 5(1), 57-70.

[14] Agarwal, V., \&Taffler, R. (2008). Comparing the performance of market-based and accounting-based bankruptcy prediction models. Journal of Banking \& Finance, 32(8), 1541-1551.

\section{Volume 8 Issue 4, April 2019 www.ijsr.net}




\section{International Journal of Science and Research (IJSR) \\ ISSN: 2319-7064}

ResearchGate Impact Factor (2018): 0.28 | SJIF (2018): 7.426

[15] Nam, C. W., Kim, T. S., Park, N. J., \& Lee, H. K. (2008). Bankruptcy prediction using a discrete-time duration model incorporating temporal and macroeconomic dependencies. Journal of Forecasting, 27(6), 493-506.

[16] Bellovary, J. L., Giacomino, D. E., \& Akers, M. D. (2007). A review of bankruptcy prediction studies: 1930 to present. Journal of Financial education, 1-42.

[17] Warren, C., Reeve, J., Duchac, J. 2009 Accounting CENGAGE Learning

[18] Tirapat, S., \&Nittayagasetwat, A. (1999). An investigation of the listed firms' financial distress using macro and micro variables. Multinational Finance Journal, 3(2), 103-125.

[19] Cowen, S. S., \& Hoffer, J. A. (1982). Usefulness of financial ratios in a single industry. Journal of Business Research, 10(1), 103-118.

[20] Ali, K. A. (2008). Financial Analysis And Its Uses To Control The Performance And Detect Deviations, Arab Open Academy in Denmark College (Doctoral dissertation, Master's Thesis).

[21] Jones, F. L. (1987). Current techniques in bankruptcy prediction. Journal of accounting Literature, 6(1), 131164.

[22] Platt, H. D., \& Platt, M. B. (2002). Predicting corporate financial distress: reflections on choice-based sample bias. Journal of Economics and Finance, 26(2), 184199.

[23]Zeytinoglu, E., \&Akarim, Y. D. (2013). Financial failure prediction using financial ratios: An empirical application on the Istanbul Stock Exchange. Journal of Applied Finance and Banking, 3(3), 107.

[24] Chava, S., \&Jarrow, R. A. (2004). Bankruptcy prediction with industry effects. Review of Finance, 8(4), 537-569.

[25] Nissim, D., \& Penman, S. H. (2001). Ratio analysis and equity valuation: From research to practice. Review of accounting studies, 6(1), 109-154.

[26] Gerantonis, N., Vergos, K., \&Christopoulos, A. (2009). CAN ALTMAN Z-SCORE MODEL PREDICT BUSINESS FAILURES IN GREECE?. In Proceedings of the 2nd International Conference: Quantitative and Qualitative Methodologies in the Economic and Administrative Sciences (p. 149). Christos Frangos.

[27] Summers, S. L., \& Sweeney, J. T. (1998). Fraudulently misstated financial statements and insider trading: An empirical analysis. Accounting Review, 131-146.

[28] Karamzadeh, M. S. (2013). Application and Comparison of Altman and Ohlson Models to Predict Bankruptcy of Companies,". Research Journal of Applied Sciences, Engineering, and Technology, 5(6), 2007-2011.

[29] Petrick, J. A., \& Scherer, R. F. (2003). The Enron scandal and the neglect of management integrity capacity. American Journal of Business, 18(1), 37-50.

[30] Li, Y. (2010). The case analysis of the scandal of Enron. International Journal of Business and Management, 5(10), 37 .

[31] Nelson, K. K., Price, R. A., \&Rountree, B. R. (2008). The market reaction to Arthur Andersen's role in the Enron scandal: Loss of reputation or confounding effects?. Journal of Accounting and Economics, 46(2), 279-293.

[32] edge.pse.com.ph/page/faqs.doerepository.uonbi.ac.ke:80 80/xmlui/bitstream/handle/11295/9904/aibuma2011submission $236 \% 20$ -

\%20EVALUATION\%20OF\%20APPLICABILITY\%20 OF\%20ALTMAN'S\%20REVISED\%20MODEL\%20IN $\% 20$ PREDICTION\%20OF\%20FINANCIAL\%20DIST RESS.pdf;sequence $=1$

\section{Author Profile}

Cerenio Adriatico currently teaches accounting, finance, development economics both in the undergraduate and graduate programs of Southern Leyte State University - College of Business and Management and Southern Leyte State University- Graduate School. 